\title{
Hypouricemic Activity of Pentopetia Androsaemifolia Decne. (Apocynaceae) Hydro Alcoholic Extract in Mice
}

\author{
Randrianavony P., PhD \\ Reboza A. M.., MSc
}

Laboratoire de Pharmacologie Générale, de Pharmacocinétique et de Cosmétologie, Faculté des Sciences, Université d'Antananarivo, Madagascar Quansah N., PhD

SIT Study Abroad Summer Program: Madagascar Traditional Medicine and Health Care Systems, Antananarivo, Madagascar

Randimbivololona F., PhD

Laboratoire de Pharmacologie Générale, de Pharmacocinétique et de Cosmétologie, Faculté des Sciences, Université d'Antananarivo, Madagascar

Doi: 10.19044/esj.2017.v13n36p340 URL:http://dx.doi.org/10.19044/esj.2017.v13n36p340

\begin{abstract}
The aim of this work was to investigate the uricemic and uricosuric activity of the hydro alcoholic extract of Pentopetia androsaemifolia in experimentally induced hyperuricemic mice. Hyperuricemia was induced in the mice by intraperitoneal injection of potassium oxonate. Oral administration of the extract at doses 50 to $200 \mathrm{mg} / \mathrm{kg}$ reduce hyperuricemia from $218.78 \pm 7.50$ to $72.29 \pm 16.88 \mathrm{mg} / 1(\mathrm{P}<0.05)$. The same doses of 50 to $200 \mathrm{mg} / \mathrm{kg}$ of the extract also reduce uricosuria from $125.4 \pm 4.4$ to $70 \pm$ $12.6 \mathrm{mg} / \mathrm{l}(\mathrm{p}<0.05)$. A direct correlation exists between plasma uric acid concentration and urine uric acid concentration $(r=0.99)$. The hypouricemic activity of the extract could be due to xanthine oxidase inhibition by the flavonoids present in the extract.
\end{abstract}

Keywords: Pentopetia androsaemifolia, hyporuricemic, gout

\section{Introduction}

Gout is a metabolic disease characterized by hyperuricemia, with a blood concentration superior to $420 \mu \mathrm{mol} / \mathrm{L}$ (70 mg/L) (Bardin, 2007; Merriman T.R., and Dalbeth, 2011). Beyond this concentration, sodium urate precipitates in tissues, particularly in joints, provoking inflammatory reactions (Prigent \& Berets, 1992). Acute gout can disappear on its own 
within a short time without treatment. Whereas in the chronic state, it can lead to damages in joints and end up to be a permanent polyarthritis (Edwards et al., 2011).

Treatment of gout can be symptomatic with nonsteroidal antiinflammatory drugs, or in reducing uricemia by inhibiting xanthine oxidase (Choi et al., 2005; Terkeltaub, 2003) or increasing uricosuria (Suresh \& Das, 2012).

In the semi desert zone of the south of Madagascar, the local community is herdsmen, and their main diet is beef. This population often suffers from joint problems, especially of the big toe. Drinking the beverage prepared with the leaves of Pentopetia androsaemifolia relieves the pain and reduces the edema. This field observation is the basis of our hypothesis, that this decoction may reduce uricemia or increase uricosuria.

\section{Materials and methods}

The materials for this study were the leaves of Pentopetia androsaemifolia collected from the southern region of Madagascar in December 2015.

\section{Preparation of the extract}

The leaves were dried in shade, aerated, at room temperature, and grounded. Five hundred grams of the powder were macerated 5 days in 5 liters of ethanol-water mixture (60:40), at room temperature. This macerate was filtered using Whattman paper $\mathrm{n}^{\circ} 3$, and the filtrate was evaporated to dryness under vacuum with a rotative evaporator Evapotec ${ }^{\circledR}$ at the temperature of $80^{\circ} \mathrm{C}$.

\section{Animal used}

Albino mice, Swiss strain, of both sexes, aged 8 weeks, weighing 200 to $210 \mathrm{~g}$ were used during the experiments. The animals were bred in the animal house of the Laboratoire de Pharmacologie Générale, de Pharmacocinétique et de Cosmétologie (LPGPC) of the Science Faculty, University of Antananarivo, at a temperature of $22 \pm 2^{\circ} \mathrm{C}$ and kept under 12h/12h light/dark cycle. They were fed with LFL $1040^{\circledR}$ pelleted feed and had water ad libitum.

The mice were experimentally induced hyperuricemic by intraperitoneal injection of potassium oxonate aqueous solution at the dose of 200 $\mathrm{mg} / \mathrm{kg}$ (Vogel et al., 2002; Huang et al., 2008).

$\mathrm{BIOLAB}^{\circledR}$ reagent made of $42 \mu \mathrm{mol} / 1$ of potassium hexacyanoferrate, $450 \mathrm{Ul}$ of peroxidase, $0.150 \mathrm{mmol} / 1$ of amino-antipyrine and $120 \mathrm{Ul}$ of uricase, was used to dosage the uric acid concentration in the samples. 


\section{Study of the extract effect on uricemia}

The extract was dissolved in distilled water. The induced hyperyricemic animals were divided into 4 groups: one group served as control and 3 treated with the extract at 3 different doses. The control group received $10 \mathrm{ml} / \mathrm{kg}$ of distilled water, while the other groups were orally administered the extract at doses 50,100 , and $200 \mathrm{mg} / \mathrm{kg}$ respectively in 10 $\mathrm{ml} / \mathrm{kg}$ of distilled water (Vogel et al., 2002).

Two hours after, the maxillary vein of the animal was pinpricked with a sterile pin. The blood was collected in non-heparinized glass tube, and centrifuged for 10 minutes at $3000 \mathrm{rpm}$ with EBA $3 \mathrm{~S}^{\circledR}$ centrifuge (Elin et al., 1982).

After centrifugation, $25 \mu \mathrm{l}$ of supernatant were placed in glass tube containing $1 \mathrm{ml}$ of $\mathrm{BIOLAB}^{\circledR}$ reagent. The mixture was left at room temperature for 5 minutes.

The concentration of uric acid in the samples was determined by colorimetric technic, using APUS ${ }^{\circledR}$ colorimeter, at the wavelength $\lambda=520$ $\mathrm{nm}$, and a standard solution provided with the reagent (Wang et al., 2010).

\section{Study of the extract effect on uricosuria}

A raw beef juice was prepared by mixing $250 \mathrm{~g}$ of beef and $250 \mathrm{ml}$ of $9 \% \mathrm{NaCl}$ in a blender, used as source of purine. The extract was dissolved in this juice. All the animals were injected intra peritoneally with $200 \mathrm{mg} / \mathrm{kg}$ of potassium oxonate (Vogel, 2002; Huang et al., 2008). One hour after, the animals were divided into 4 groups; one group serving as control, and 3 groups treated with the extract. The control group animals received $10 \mathrm{ml} / \mathrm{kg}$ of the beef juice while the 3 groups, were respectively administered by oral route the beef juice containing 50,100, and $200 \mathrm{mg} / \mathrm{kg}$ of the extract in 10 $\mathrm{ml} / \mathrm{kg}$ (Vogel et al., 2002).

Afterwards, they were put individually in metabolism cages for 24 hours. Their urine were collected, and centrifuged for 10 minutes at 3000 $\mathrm{rpm}$. The supernatant was recuperated, and $25 \mu \mathrm{l}$ of it was placed in glass tube containing $1 \mathrm{ml}$ of $\mathrm{BIOLAB}^{\circledR}$ reagent. The mixture was left at room temperature for 5 minutes.

After this reaction, the uric acid concentration in the samples was determined. APUS ${ }^{\circledR}$ colorimeter was used at the wavelength of $\lambda=520$ $\mathrm{nm}$, and a standard provided with the reagent was used to determine the concentration of uric acid in the samples.

\section{Relation between uricemia and uricosuria}

Linear regression was established to evaluate the relation between uricosuria, uricemia and the dosage of the extract. 


\section{Analysis and expression of results}

Results were expressed as mean \pm s.e.m. They were compared using the Student ' $\mathrm{t}$ ' test. A value of $\mathrm{P}<0.05$ was considered significant.

\section{Results \\ Effect of the extract on uricemia and uricosuria}

The uricemia and uricosuria of the induced hyperuricemic mice by intra peritoneal injection of potassium oxonate and treated with the alcoholic extract of $P$. androsaemifolia are inferior to those of the hyperuricemic control groups $(\mathrm{P}<0.05)$ (Table I).

Table I. Variation of uricemia and uricosuria of hyperuricemic mice, induced by potassium oxonate $200 \mathrm{mg} / \mathrm{kg}$ injected i.p. in the control group and treated with $P$. androsaemifolia alcoholic extract, administered by oral route, at the doses of 50, 100 and $200 \mathrm{mg} / \mathrm{kg} .(\bar{m} \pm$ e.s.m; $\mathrm{n}=5 ; * \mathrm{P}<.05)$.

\begin{tabular}{|c|c|c|c|c|}
\hline Animals & Control group & \multicolumn{2}{|c|}{ Treated with extract dissolved in beef juice } \\
\hline $\begin{array}{c}\text { Dosage } \\
(\mathrm{mg} / \mathrm{kg})\end{array}$ & Beef juice & 50 & 100 & 200 \\
\hline Uricemia $(\mathrm{mg} / \mathrm{l})$ & $227.89 \pm 18.80$ & $218.78 \pm 7.50^{*}$ & $137.86 \pm 30.42^{*}$ & $72.29 \pm 16.88^{*}$ \\
\hline Uricosuria $(\mathrm{mg} / \mathrm{l})$ & $148 \pm 1.4$ & $125.4 \pm 4.4^{*}$ & $92.6 \pm 10.1^{*}$ & $70 \pm 12.6^{*}$ \\
\hline
\end{tabular}

The correlation between the uricemia and uricosuria variation is very high $(\mathrm{r}=0.99)$.

\section{Discussion}

Mouse was used as experimental model in this experiment, because the urate elimination in mouse is similar to that of humans (Ding et al., 2005). Injection of potassium oxonate by intra peritoneal route and the juice prepared with raw beef increase the uric acid concentration in the blood (Vogel et al., 2002; Fukunari et al., 2004; Wang et al., 2010). Meanwhile, uricemia and uricosuria in animals treated with the alcoholic extract of $P$. androsaemifolia diminished, compared to the control group.

The main route of elimination of uric acid is the urinary tract. The diminution of uricemia could be explained by the increasing of uricosuria. Meanwhile, in this experiment, within the dosages used, the two parameters variate in the same way; both of them diminish in the treated animals.

This result means that the extract reduces the uricosuria and uricemia at the same time. Which let us deduce that the decrease in the concentration of uric acid in the urine is due to the reduction of the plasma uric acid concentration. From this observation, we advance a hypothesis that the alcoholic extract of $P$. androsaemifolia have diminished the plasma uric acid concentration by inhibiting its synthesis. The extract might inhibit the xanthine oxidase responsible for the synthesis of the uric acid (Zhifeng et al., 2005; Huang et al., 2008). 


\section{Conclusion}

Our results show that the alcoholic extract of Pentopetia androsaemifolia reduces both uricemia and uricosuria in hyperuricemic mice. This activity could be due to the inhibition of xanthine oxidase responsible for the synthesis of uric acid.

\section{References:}

1. Bardin, T. (2007). Epidémiologie de la goutte. Revue du rhumatisme, 74: 147-149.

2. Choi, H.K., Mount, D.B. \& Reginato, A.M. (2005). Pathogenesis of gout. Ann. Int. Med., 143(7): 499-516.

3. Ding, Z., Dai Y. \& WANG, Z. (2005). Hypouricemic action of scopoletin arising from xanthine oxidase inhibition and uricosuric activity. Planta Medica, 71: 183-185.

4. Elin, R.J., Johnson, E. \& Chesler R. (1982). Four methods for determining uric acid. Clin. Chem., 28 (10): 2098-2100.

5. Edwards, N.L., Sundy, J.S., Forsythe, A., Blume, S., Pan, F. \& Becker, M.A. (1977). Work productivity loss due to flares in patients with chronic gout refractory to conventional therapy. J. Med. Econ., 14: 10-5.

6. Fukunari, A., Okamoto, K., Nishino, T., Eger, B.T.E., Pai E.F., Kamezawa, M., Yamada, I. \& Kato N. (2004). Y-700[1-[3-cyano-4(2,2-dimethylpropoxy) phenyl]-1Hpyrazole-4-carboxylic acid] a potent xanthine oxido reductase inhibitor with hepatic excretion. $J$. Pharmacol. Exp. Ther., 311 (2): 519-528.

7. Huang, C. G., Shang, Y. J., Zhang, J. R., Li W. J. \& Jiao B. H. (2008). Hypouricemic effect of phenyl propanoid glycosides acteoside of Scrophularia ningpoensis on serum uric acid levels in potassium oxonate - pretreated mice.

8. Am. J. Chin. Med., 36 (1): 149-157.

9. Merriman, T. R. \& Dalbeth, N. (2010). Bases génétiques de l'hyperuricémie et de la goutte. Revue du rhumatisme 77: 328-334.

10. Prigent, D. \& Berets, O. (1992). Epidémiologie de la goutte et hyperuricémie: déductions physiopathologiques. Revue Médecine et armées, 7 (20): 585-589.

11. Suresh, E. \& Das, P. (2012). Recent advances in management of gout. Int. J. Med., 105 (5): 407-417.

12. Terkeltaub, R.A. (2003). Gout. New Engl. J. Med., 349 (17): $1647-$ 1655.

13. Vogel, H. G., Scholkens, B. A., Sandow, J., Muller, G. \& Vogel W. F. (2002). 
14. Drug discovery and evaluation: pharmacology assays. 2nd Ed. Springer Verlag, Germany, 112-113.

15. Wang, C. P., Wang, X., Zhang, X., Shi, Y. W., Liu, L. \& Kong, L. D. (2010). Morin improves urate excretion and kidney function through regulation of renal organic ion transporters in hyperuricemic mice. $J$. Pharm. Pharmac. Sci., 13 (3): 413-424.

16. Zhifeng, Y., Fong, W.P. \& Cheng, C. H. K. (2005). The dual actions of morin (3,5,7,2,4-Pentahydroxyflavone) as a hypouricemic agent: uricosuric effect and xanthine oxidase inhibitory activity. J. Pharmacol. Exp. Ther., 316 (1): 170-171. 